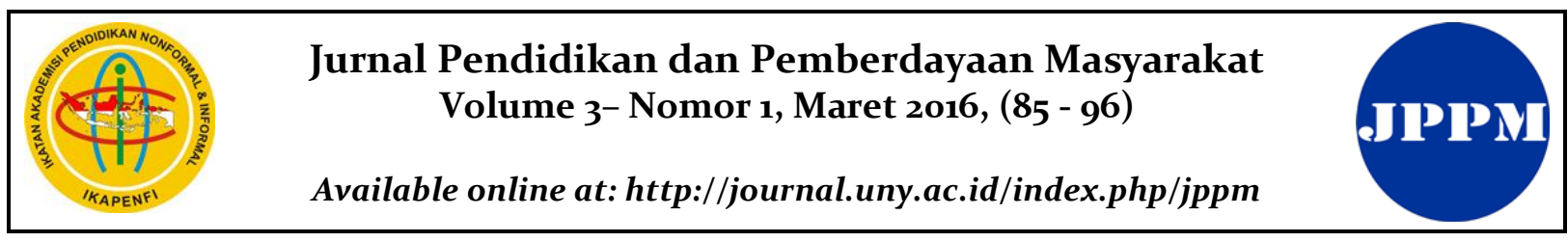

\title{
EVALUASI PEMBELAJARAN KETERAMPILAN MEMBACA PERMULAAN DI TK FASTRACK FUNSCHOOL KELAS A PROGRAM NUSANTARA YOGYAKARTA
}

\author{
Syarifatul Fitria ${ }^{1)}$, Suparno ${ }^{2)}$ \\ ${ }^{1}$ Fastrack Funschool Yogyakarta, Jl. Perumnas, Mundusaren, Sleman, Indonesia. \\ Email: syarifatulfitria@gmail.com \\ ${ }^{2}$ Pendidikan Luar Biasa, Universitas Negeri Yogyakarta. Jl. Colombo No. 1 Yogyakarta 55281, \\ Indonesia. Email: suparno_plb@uny.ac.id
}

\begin{abstract}
Abstrak
Penelitian ini bertujuan untuk mengetahui hasil evaluasi pembelajaran keterampilan membaca permulaan di TK Fastrack Funschool kelas A Program Nusantara dengan melihat efektifitas pelaksanaan dan hasil pencapaian keterampilan membaca permulaan anak. Penelitian ini menggunakan pendekatan penilaian otentik dan evaluasi datanya menggunakan data formatif dan data sumatif. Subjek penelitian adalah seluruh anak TK Fastrack Funschool kelas A Program Nusantara sebanyak 15 anak. Pengumpulan data menggunakan lembar observasi check list dan lembar observasi rating scale. Analisis data menggunakan statistik deskriptif eksploratif dengan persentase. Hasil penelitian menunjukkan bahwa hasil evaluasi formatif maupun sumatif keterampilan membaca permulaan anak kelas A Program Nusantara berdasarkan indikator mampu menyebutkan nama karakter huruf, mampu menyebutkan bunyi huruf, mampu mencocokkan huruf besar dan kecil, mampu menyebutkan tulisan sederhana dengan simbol yang melambangkannya, secara umum bisa dikategorikan "berkembang sangat baik" karena 93,33\% dari jumlah keseluruhan anak dalam kelas tersebut memiliki persentase pencapaian penguasaan materi antara $75 \%-100 \%$. Melalui penelitian ini diketahui bahwa metode pembelajaran membaca permulaan yang diterapkan menunjukkan bahwa anak-anak memiliki antusiasme dan keaktifan yang dikategorikan "berkembang sesuai harapan" dalam mengikuti pembelajaran membaca permulaan.

Kata Kunci: evaluasi, membaca permulaan, taman kanak-kanak
\end{abstract}

\section{AN EVALUATION OF THE TEACHING OF FIRST READING SKILLS IN KINDERGARTEN FASTRACK FUNSCHOOL CLASS A NUSANTARA PROGRAM YOGYAKARTA}

\begin{abstract}
This study aims to reveal the results of the evaluation of teaching process of first reading skills in Kindergarten Fastrack Funschool class A Nusantara Program from the effectiveness of the implementation and results of child's first reading skill achievement. This study used the approach of authentic assessment and evaluation of data using the data formative and the data summative. The subject were 15 students of Kindergarten Class A Nusantara Program. The data were collected using a check list observation sheet and rating scale observation sheet and analyzed using the quantitative explorative statistics with percentage. The results show that the results of formative and summative evaluation of first reading skills of grade A students of Nusantara Program ability based on four indicators, in general it can be categorized as "developing very well" because $93.33 \%$ of the children in the class have a percentage attainment of mastery of the material between $75 \%-100 \%$. Through this study, it is also noted that the teaching method indicate that students have the enthusiasm and liveliness that can be categorized as "developing according to expectations "in following the teaching process of first reading.
\end{abstract}

Keywords: evaluation, beginning reading, kindergarten

How to Cite: Fitria, S., \& Suparno, S. (2016). Evaluasi pembelajaran keterampilan membaca permulaan di TK Fastrack Funschool Kelas A Program Nusantara Yogyakarta. Jurnal Pendidikan dan $\begin{array}{lllll}\text { Pemberdayaan } \quad \text { Masyarakat, } & 3(1), & \text { 85-96. } & \text { Retrieved from }\end{array}$ http://journal.uny.ac.id/index.php/jppm/article/view/6481 


\title{
Jurnal Pendidikan dan Pemberdayaan Masyarakat, 3 (1), Maret 2016 - 86
}

\author{
Syarifatul Fitria, Suparno
}

\section{PENDAHULUAN}

Proses pembelajaran pada anak usia dini akhir-akhir ini menjadi isu yang menarik bagi banyak kalangan. Pemerintah, masyarakat, pendidik dan orang tua semakin menaruh perhatian pada anak usia dini, karena semakin tingginya kesadaran akan pentingnya optimalisasi potensi masa keemasan pada anak usia dini. Salah satu hal yang diperhatikan dalam proses pembelajaran anak usia dini adalah proses mengembangkan kemampuan membaca anak. Di Indonesia, kemampuan membaca pada anak dianggap sebagai sesuatu yang penting. Banyak orang tua berpendapat bahwa membuat anak mereka mampu membaca sedini itu sangat penting. Hal ini dikarenakan keterampilan membaca anak dianggap penting untuk membantu anak mengikuti proses pembelajaran di sekolah formal.

Salah satu alasan orang tua terkesan "memaksakan" anak untuk bisa membaca adalah agar anaknya bisa masuk ke sekolah favorit yang biasanya menuntut keterampilan membaca ketika memasuki kelas 1 SD (Kumara, et. al, 2014, p.vii). Fenomena tersebut bertentangan dengan Peraturan Pemerintah Nomor 17 tahun 2010 pasal 69 poin 5 menyatakan bahwa penerimaan peserta didik kelas 1 (satu) SD/MI atau bentuk lain yang sederajat tidak didasarkan pada hasil tes kemampuan membaca, menulis, dan berhitung, atau bentuk tes lain. Walaupun dalam kurikulum taman kanak-kanak yang dikeluarkan oleh Direktorat Pembinaan Taman Kanak-kanak dan Sekolah Dasar tahun 2010 menyatakan bahwa salah satu kompetensi kognitif pada anak TK kelompok A (4-5 tahun) yaitu mengenal lambang huruf.

Permasalahan utama pengenalan bacatulis di kelompok bermain (KB) dan Taman kanak-kanak (TK) menyangkut tiga hal pokok yaitu pertama, permasalahan metode atau model baca-tulis yang digunakan oleh guru, terutama karena metode fonik maupun kata utuh sama-sama tidak bisa berdiri sendiri-sendiri (Field, 2005). Kedua, permasalahan pendekatan pembelajaran, cara-cara pemaksaan dalam belajar tidak akan membuat anak memperoleh ilmu, tetapi justru akan kehilangan masa-masa emas proses pemerolehan mental (Bodrova \& Leong, 1996, dalam Musfiroh, 2010, p. 27). Ketiga, permasalahan media dan sumber yang digunakan, penggunaan bentuk tulisan tak bermakna tidak bersifat fungsional dan hal tersebut bertentangan dengan konsep pemerolehan bahasa (Steinberg, 2001).

Bodrova, Leong \& Paynter (1999, p.43) menyatakan bahwa mengajarkan materi atau keterampilan tertentu pada anak usia dini sangat berbahaya jika tidak sesuai dengan tahap perkembangan anak, karena hal tersebut sama dengan mempercepat perkembangan anak yang dapat merusak kemampuan belajar anak pada waktu yang akan datang. Pendapat ini menunjukkan betapa pentingnya memperhatikan faktor perkembangan kemampuan anak sebagai dasar untuk menyusun standar literasi/membaca bagi anak usia dini.

Sebenarnya mengajarkan anak usia dini membaca tidak selalu memiliki sisi negatif. Beberapa penelitian membuktikan, bahwa memberikan pembelajaran keterampilan membaca pada anak usia dini memiliki peran penting bagi kesiapan anak pada jenjang pendidikan berikutnya. Hal ini dinyatakan dalam studi yang dilakukan oleh Spira, Bracken dan Fischel (dalam Papalia \& Feldman, 2014, p.336) bahwa anak-anak yang menunjukkan perkembangan kemampuan membaca yang paling besar adalah anak yang saat masih duduk di bangku TK memiliki kemampuan dalam memahami huruf yang kuat dan tingkah laku di kelas baik, serta mereka memperhatikan dan mengambil manfaat dari pelajaran tersebut.

Brown (2014, pp 24-25) menyatakan bahwa kualitas pendidikan anak usia dini yang tinggi penting untuk memastikan keberhasilan kemampuan akademis anak jangka panjang. Semua anak dapat mengembangkan pondasi yang kuat untuk melek huruf dan perkembangan membaca ketika mereka diberi kesempatan untuk terlibat dalam kegiatan yang memiliki tujuan, bahasa bermakna dan kegiatan yang berhubungan dengan kemampuan huruf cetak awal.

Hasil penelitian Denton \& West (2002, p.vii) menunjukkan, bahwa keterampilan membaca dan numerasi permulaan pada 


\section{Jurnal Pendidikan dan Pemberdayaan Masyarakat, 3 (1), Maret 2016 - 87}

Syarifatul Fitria, Suparno

saat TK mempunyai sumbangan positif terhadap kemampuan dan keterampilan membaca serta matematika anak pada saat di TK dan kelas 1 SD. Oleh sebab itu, keberhasilan proses pembelajaran membaca permulaan sangat penting untuk menjadi landasan kemampuan membaca selanjutnya dan kemampuan akademik lainnya. Menurut Levey \& Berstein (dalam Levey \& Polirstok, 2011, p. 152) kesadaran membaca tulisan mucul ketika anak mulai memahami tentang arti dari tulisan. Di usia 4 tahun, anak mampu mengingat tulisan nama mereka. Di usia 5 sampai 7 tahun anak belajar tentang hubungan antara suara/bunyi dan huruf dalam kata.

Pembelajaran membaca untuk anak usia dini khususnya, anak-anak harus mendapatkan perlakuan khusus sesuai dengan tahap perkembangannya. Artinya dari segi kurikulum, materi ajar dan juga model yang digunakan harus berorientasi pada kondisi emosional dan psikologis anak. Orang tua dan guru seharusnya memperhatikan modelmodel pembelajaran membaca pada anak secara menyeluruh dengan memperhatikan berbagai aspek tersebut, sehingga anak-anak merasa nyaman dan senang dalam belajar membaca. 'senang' dan 'nyaman' merupakan kata kunci dalam proses pembelajaran membaca untuk anak. Jadi selama proses pembelajaran tersebut anak harus merasa senang dengan materi yang diajarkan oleh guru maupun orang tua dan kunci kesenangan tersebut terletak pada model ajar yang digunakan. Kondisi belajar yang menyenangkan secara otomatis akan membuat anak-anak merasa nyaman dalam proses pembelajaran membaca permulaan. Kondisi dan situasi yang menyenangkan bisa diciptakan melalui penataan ruang dan juga alat peraga serta model yang digunakan. Oleh karena itu, persiapan sebelum mengajar bagi guru sangat penting, karena hal ini akan memberikan garis petunjuk dalam proses belajar mengajar.

Pada tahun 2011-2013 TK Program Nusantara Fastrack Funschool mengajarkan keterampilan membaca permulaan dengan model tradisional yaitu hafalan huruf, menyebutkan huruf demi huruf, mengeja huruf-huruf yang dirangkai menjadi suku kata, mengeja huruf demi huruf dalam sebuah kata. Dari hasil pengamatan dan pencatatan yang dilakukan oleh guru kelas, anak-anak yang diajarkan mengenal huruf dengan model tradisional memiliki beberapa kendala untuk mengingat nama hurufnya. Ketika anak diajarkan untuk membaca kata sederhana, mereka mengalami kesulitan untuk menggabungkan bunyi huruf dalam kata tersebut. Anak-anak juga cenderung mengeluh enggan untuk belajar membaca huruf. Oleh karena itu pada tahun ajaran baru 2013-2014, TK Program Nusantara Fastrack Funschool mencoba mengembangkan model pengajaran membaca permulaan untuk pengenalan huruf dengan membuat huruf-huruf tersebut menjadi suatu tokoh/ karakter dan memiliki suara. Model pengajaran karakter huruf dan suara ini sudah diterapkan di TK A program Nusantara Fastrack Funschool kurang lebih selama 1,5 tahun. Saat ini merupakan angkatan kedua anak-anak yang diberikan materi pembelajaran permulaan dengan menggunakan model ini, namun model baru ini belum pernah diteliti efektifitas kegunaannya untuk membuat anak-anak lebih mudah menguasai keterampilan membaca permulaan dan membuat anak-anak menjadi lebih antusias belajar membaca.

Model ini mengadaptasi model pembelajaran letterland yang berasal dari Inggris. Model pembelajaran letterland ada lebih dari 30 tahun yang lalu yakni belajar membaca dan mengejakan bahasa inggris. Model letterland diyakini bahwa proses belajar membaca akan berhasil dengan baik jika seluruh aspek kecerdasan setiap anak diikutsertakan. Model mengajar letterland juga ditujukan untuk menstimulasi area utama belajar anak (multiple intelligence) seperti kemampuan linguistik, kemampuan logis/ analitis, kemampuan spasial, kemampuan kinestetik, kemampuan musikal, kemampuan interpersonal dan intrapersonal (Freese, 2003).

Model letterland menghadirkan anakanak dalam dunia paralel, yakni membuat huruf-huruf yang sifatnya abstrak bagi mereka dijadikan sesuatu yang konkrit, dengan analogi yang diambil dari kehidupan nyata. Karakter gambar yang menjadi daya tarik 
anak untuk mempelajari huruf yang berwarna hingga huruf yang hitam polos. Cerita logis imajinatif membantu anak untuk mengingat fonik/bunyi yang relevan dengan huruf yang diceritakan melalui perumpamaan, metafora dan dongeng (Freese, 2003). Model ini menyatakan menggunakan pendekatan sistematis yang eksplisit, model ini dipertimbangkan sebagai model fonik yang lebih disukai untuk pengajaran abjad di Inggris (Department of Education, Science and Training dalam Campbell, Torr, Cologon, 2012).

Model ini juga dirancang dengan menggunakan pendekatan 'Total Physical Response' (TPR) yang mana melalui pendekatan ini anak usia dini yang belum memahami konsep abstrak, belajar dengan pengalaman langsung melalui lima inderanya (Reilly \& Ward, 2002, p.9). Ini artinya anakanak melakukan atau mengekspresikan apa yang guru bicarakan. Pendekatan ini mencoba untuk mengkonkritkan huruf-huruf yang abstrak tersebut menjadi sesuatu yang tampak nyata dan dekat dengan kehidupan anak-anak yaitu menjadikan huruf tersebut menjadi tokoh imajinatif dan disampaikan melalui proses bercerita dan bergerak sesuai dengan karakter huruf yang diperkenalkan.

Melalui pendekatan TPR ini guru juga bisa mengembangkan aktivitas pembelajaran membaca permulaan dengan karakter huruf dan suara tersebut melalui permainan, gerak dan lagu, hasil karya, bermain peran dan lain-lain. Penelitian yang dilakukan oleh Adedokun (2013, p.470) menunjukkan bahwa kegiatan keaksaraan yang efektif dalam meningkatkan dan mengembangkan keterampilan keaksaraan yaitu dengan rutinitas membaca bersama, mengunakan buku yang sesuai dengan usia anak, membaca sajak anak-anak, dan menyanyikan lagu.

Berdasarkan model letterland tersebut maka Fastrack Funschool mencoba untuk mengembangkan model membaca bahasa indonesia dengan model yang mengadaptasi sistem letterland yang menggunakan pendekatan fonik, TPR dan multiple intelligence dalam pembelajarannya, dengan perubahan karakter tokoh dan suara yang disesuaikan dengan karakter yang dekat dengan anak- anak Indonesia dan suara huruf bahasa Indonesia.

Papalia \& Feldman (2014, p. 335) menyatakan bahwa anak dapat mengenali katakata dengan dua cara yaitu decoding dan visual berbasis pengulangan. Decoding yaitu anak menyuarakan kata tersebut, mengubah dari tulisan menjadi ucapan sebelum menyimpannya dalam memori jangka panjang. Untuk dapat melakukan ini, seorang anak harus menguasai kode fonetik, sehingga kata yang tertulis berbunyi sesuai dengan pengucapannya. Metode yang lain adalah dengan visual berbasis pengulangan yaitu cara ini secara sederhana meminta anak untuk melihat kata yang tertulis kemudian mengulanginya. Visual berbasis pengulangan merupakan proses pengulangan suara dari katakata yang dicetak dengan melihat kata-kata sebagai satu kesatuan. Kedua metode ini berasal dari dua pendekatan yang berbeda.

Pendekatan secara tradisional yang menekankan pada metode decoding disebut sebagai pendekatan penekanan kode. Pendekatan yang lebih baru menekankan pada pengulangan secara visual dan menggunakan petunjukkan kontekstual. Pemrakarsa metode ini menegaskan bahwa anak mampu belajar membaca dengan lebih komprehensif dan lebih menyenangkan jika mereka telah memahami bahasa tulisan sejak awal untuk memperoleh informasi dan mengekspresikan ide dan perasaan, bukan sebagai sistem yang mengisolasi suara dan dapat dipahami melalui proses mengingat dan latihan. Meskipun pendekatan ini sangat populer, penelitian menemukan sedikit dukungan terhadap klaim ini. Suatu penelitian jangka panjang mendukung pandangan bahwa kesadaran fonemik dan latihan fonetik sejak dini adalah kunci bagi tiap anak untuk dapat mahir membaca.

Parlapiano dalam buku early childhood education becoming professional (Gordon, et.al, 2014) mengemukakan tahapan capaian perkembangan keterampilan membaca pada anak usia TK yaitu: (a) mengenali huruf abjad, (b) mengenali dan menghubungkan kurang lebih 20 huruf dan suara/bunyinya, (c) mulai memiliki pemahaman tentang kesadaran fonemik (masing-masing kata memiliki suara sendiri), (d) mulai membaca 


\section{Jurnal Pendidikan dan Pemberdayaan Masyarakat, 3 (1), Maret 2016 - 89}

Syarifatul Fitria, Suparno

dan menulis konsonan sederhana-huruf vokal-kata konsonan, (e) mengenal beberapa kata sederhana.

Ada banyak metode pembelajaran yang dapat dikembangkan dan diterapkan di taman kanak-kanak. Namun yang terpenting dalam mengembangkan metode pembelajaran bagi pendidikan anak usia dini harus memperhatikan karakteristik anak dan kompetensi yang akan dicapai, interaksi dalam proses pembelajaran, alat/media dan penilaian. Dalam hal interaksi dalam proses pembelajaran penting juga untuk memperhatikan interaksi anak dengan teman maupun interaksi anak dengan guru selama proses pembelajaran, seperti halnya penelitian yang dilakukan oleh Fantuzzo, Sutton Smith, Coolahan, Manz, Canning, dan Debnam (dalam Johnson, 1999, p.236) dalam mengembangkan penn interactive peer play scale salah satu aspeknya adalah interaksi anak dalam bermain yaitu dimensi positif yang terkait dengan perilaku prososial, kemampuan interpersonal, kontrol diri, dan ketegasan lisan. Oleh karena berdasarkan sifat dan karakter anak usia dini, maka pembelajaran di taman kanak-kanak bersifat tematik yang dilakukan secara integratif, artinya bahwa pembelajaran di taman kanak-kanak tidak bisa dilakukan dengan metode tunggal. Itulah sebabnya, model pembelajaran yang dikenalkan adalah yang bersifat paduan/integral (Trianto, 2011, p.11).

Menurut Rasyid, Mansyur, \& Suratno (2012, p. 50) menyatakan juga bahwa konsep literacy yang diperdengarkan sekaligus diperlihatkan bendanya kepada anak usia dini harus didesain lewat permainan yang menyenangkan dan menggembirakan. Dalam kegiatan bermain ini anak dapat terlibat dan berpartisipasi bersama pendidik. Dengan demikian, mendengarkan bunyi dan melihat bendanya secara konkrit secara bersamaan dapat meningkatkan perkembangan berpikir pada anak usia dini, sehingga anak menjadi kaya akan informasi.

Menurut Combs (2012, p. 16) Tindakan membaca sangat kompleks, hal ini merupakan proses perkembangan interaktif yang menuntut keterlibatan pikiran dan hati anak. Selain itu keberhasilan dalam membaca dipengaruhi oleh beberapa faktor (lingkungan, fisiologis, dan psikologis) yang harus dipertimbangkan ketika menilai anak yang sedang belajar membaca sehingga intervensi yang tepat dapat digunakan.

Salah satu memengaruhi kemajuan membaca anak adalah faktor psikologis. Faktor ini mencakup (1) motivasi, (2) minat, dan (3) kematangan sosial, emosi, dan penyesuaian diri. Motivasi adalah faktor kunci dalam belajar membaca. Kuncinya adalah guru harus mendemonstrasikan kepada anak praktik pengajaran yang relevan dengan minat dan pengalaman anak memahami belajar itu sebagai suatu kebutuhan. Smith \& Johnson (1980) menyatakan bahwa motivasi intrinsik lebih kuat pengaruhnya bagi seorang pembaca menggunakan indranya dalam proses membaca, namun guru dan orang tua juga harus siap memberikan penghargaan ekstrinsik bagi anak yang membutuhkannya, karena motivasi merupakan faktor kuat yang dapat mempengaruhi perkembangan membaca. Menurut Scalon, Aderson \& Sweeney (dalam Barone \& Mallete, 2013, p. 289) motivasi untuk membaca dan menulis pada anak yaitu anak akan mengembangkan keyakinan bahwa membaca dan menulis adalah kegiatan yang menyenangkan dan informatif di luar kemampuannya.

Minat baca ialah keinginan yang kuat disertai usaha seseorang untuk membaca. Orang yang mempunyai minat membaca yang kuat akan diwujudkan dalam kesediaannya untuk mendapat bahan bacaan dan kemudian membacanya atas kesadarannya sendiri. Menurut Getzel (dalam Rasyid, Mansyur, \& Suratno, 2012) minat adalah suatu disposisi yang terorganisir melalui pengalaman yang mendorong seseorang untuk memperoleh objek khusus, aktivitas pemahaman, dan keterampilan untuk tujuan perhatian atau pencapaian. Montessori (dalam Rasyid, Mansyur, \& Suratno, 2012) menyatakan bahwa membangun minat bagi anak usia dini atau TK memerlukan tingkat intensitas tinggi melalui berbagai aktivitas bermain yang dapat meningkatkan pusat minat anak.

Menurut Witherington (dalam Arikunto, 2009, p. 217) minat adalah kesadaran seseorang bahwa suatu objek, seseorang, suatu hal atau situasi yang berkaitan 


\section{Jurnal Pendidikan dan Pemberdayaan Masyarakat, 3 (1), Maret 2016 - 90}

Syarifatul Fitria, Suparno

dengan dirinya. Minat, sering menghasilkan emosional menyenangkan, sering dianggap terkait dengan tujuan non-kompetensi dalam proses pembelajaran (Sansone \& Smith, 2000 dalam Chen \& Ennis, 2004, p.333). Pengembangan dalam penelitian pendidikan, bagaimanapun juga telah membantu peneliti mengkonsep ulang minat sebagai kerangka dikotomis yang terdiri dari kepentingan individu dan situasional. Kepentingan individu mengacu pada kondisi psikologis seseorang terhadap kegiatan atau tindakan. Minat situasional didefinisikan sebagai efek menarik dari karakteristik suatu kegiatan terhadap individu (Krapp, Hidi \& Renninger, 1992 dalam Chen \& Ennis, 2004)

Telah lama diasumsikan bahwa minat dapat memotivasi pelajar untuk mengetahui sesuatu (Dewey, 1913 dalam Chen \& Ennis, 2004). Minat belajar pada anak usia dini mesti dibangun dan ditumbuhkan melalui bermain atau aktivitas yang menumbuhkan rasa senang dan gembira dan bebas dari segala aturan yang ketat. Dengan kebebasan anak untuk memilih dan beraktivitas menurut kesenangannya, maka minat anak akan tumbuh dan berkembang, yang pada muaranya mereka menjadi senang untuk belajar dan mengeksplorasi apa saja yang disukai anak (Rasyid, Mansyur, \& Suratno, 2012). Dengan adanya minat belajar pada anak maka akan menumbuhkan motivasi belajar bagi anak. Menurut Suyadi (2010, p. 116) motivasilah yang nantinya akan menumbuhkan sikap optimistis, antusiasme, percaya diri dan tidak mudah menyerah. Motivasi adalah sesuatu yang mendorong seseorang untuk melakukan perbuatan atau tindakan guna mencapai harapan tertentu.

Menurut Barnett (dalam Johnson, 1999, p. 235) kegiatan bermain tampaknya menjadi ciri kepribadian dasar anak. Beberapa anak memiliki karakteristik kepribadian yang mempengaruhi mereka untuk sering terlibat dalam kegiatan bermain dan yang memungkinkan mereka untuk membuat dunia permainan mereka sendiri bebas dari lingkungan sekitarnya. Namun ada juga anak-anak lain yang jarang bermain sama sekali, bahkan dalam permainan yang sudah diatur sedemikian rupa. Barnett (dalam Johnson, 1999, p. 236) telah mengembang- kan skala yang memungkinkan peneliti dan guru untuk menilai kecenderungan setiap anak untuk mendekati lingkungan dalam cara yang menyenangkan. Skala ini menggunakan 5 dimensi kesenangan Lieberman yaitu spontanitas fisik, spontanitas sosial, spontanitas kognitif, manifestasi kesenangan, selera humor.

Penelitian ini bertujuan melihat efektifitas pelaksanaan dan hasil pencapaian keterampilan membaca permulaan anak di TK Fastrack Funschool kelas A Program Nusantara.

\section{METODE}

\section{Model Evaluasi}

Penelitian ini menggunakan penilaian otentik (authentic assessment) yaitu penilaian yang berdasarkan pada perilaku yang ditunjukkan oleh anak (performance-based) selama program pelaksanaan proses belajar mengajar membaca permulaan dengan metode karakter huruf dan suara. Menurut Mc Afee, Leong dan Bodrova (dalam Snow \& Van Hemel, 2008) menyatakan bahwa penilaian otentik merupakan suatu jenis penilaian kinerja/perilaku yang menggunakan tugas-tugas yang dekat dengan kehidupan sehari-hari, tantangan intelektual dan anak menyelesaikan perilaku yang diinginkan dalam konteks yang dekat dengan kehidupan sehari-hari.

Penilaian otentik merupakan proses evaluasi yang melibatkan berbagai bentuk penilaian kinerja mencerminkan belajar siswa, prestasi, motivasi, dan sikap pada kegiatan instruksional yang relevan, contoh teknik penilaian otentik termasuk penilaian kinerja, portofolio, dan penilaian diri (Callison, 1998). Penilaian otentik lebih menekan pada cara pengumpulan data dengan cara mengamati kinerja anak selama program pembelajaran berlangsung, namun dalam mengkompilasikan data evaluasi program pembelajaran akan digunakan penilaian formatif dan sumatif untuk melihat sejauhmana data yang terkumpul mampu memberikan gambaran perkembangan anak pada tiap periodenya.

Penilaian sumatif dalam membaca permulaan menurut Johnstone \& Costello 
Jurnal Pendidikan dan Pemberdayaan Masyarakat, 3 (1), Maret 2016 - 91

Syarifatul Fitria, Suparno

(melalui Goouch \& Lambirth, 2013: 104) dapat dilihat sebagai hasil assesmen dari proses pembelajaran yang sudah dilakukan. Hal ini untuk melihat sejaumana tingkat pencapaian anak dan kesuksesan guru dalam mengajar. Sedangkan penilaian formatif untuk berorientasi ke depan, hal ini terjadi selama proses pembelajaran dan diarahkan mempengaruhi kemajuan di masa depan (Crooks, melalui Goouch \& Lambirth, 2013, p. 104).

\section{Waktu dan Tempat Penelitian}

Penelitian dilaksanakan pada bulan Februari 2015 sampai dengan Mei 2015 di TK Fastrack Funschool kelas A Program Nusantara Yogyakarta yang beralamat di Jl. Perumnas Mundu-Saren, Caturtunggal, Depok, Sleman, Yogyakarta.

\section{Subjek Penelitian}

Subjek penelitian ini adalah seluruh murid TK A program nusantara Fastrack Funschool Yogyakarta yang berjumlah 15 anak.

\section{Teknik dan Instrumen Pengumpulan Data}

Penelitian ini merupakan jenis penelitian deskriptif kuantitatif dengan sifat eksploratif. Data yang diperoleh dari hasil penelitian akan diolah kemudian dideskripsikan. Data penelitian meliputi data primer kuantitatif yang diperoleh melalui catatan hasil observasi capaian perkembangan anak dalam ketrampilan membaca permulaan. Data sekunder diperoleh melalui observasi perilaku keantusiasan dan keaktifan anak selama kegiatan dilaksanakan.

Instrumen pengumpulan data dalam penelitian ini adalah dengan menggunakan lembar observasi cheklist hasil capaian belajar anak sebagai data primer. Data sekunder didapat melalui observasi rating scale. Observasi dilakukan untuk mengetahui kondisi kegiatan belajar mengajar membaca permulaan dengan metode karakter huruf dan suara di TK Program Nusantara Fastrack Funschool Yogyakarta.
Tabel 1. .Kisi-kisi Instrumen Kemampuan Membaca Permulaan usia 4-5 tahun

\begin{tabular}{c|l|l}
\hline Variabel & Sub Variabel & \multicolumn{1}{c}{ Indikator } \\
\hline & Mengenal & Mampu menyebut- \\
& nama karakter & kan nama-nama \\
& huruf & karakter huruf \\
& Mengenal & Mampu menyebut- \\
& bunyi huruf & kan bunyi huruf \\
Membaca & Mengenal & Mampu mencocok- \\
Permulaan & huruf besar & kan huruf besar \\
& dan huruf kecil & dan huruf kecil \\
& Mengenal & Menyebutkan \\
& lambang huruf & tulisan sederhana \\
& & dengan simbol \\
& & yang melambang- \\
& & kannya \\
\hline
\end{tabular}

Tabel 2. Kisi-kisi instrumen observasi keantusiasan dan keaktifan anak

\begin{tabular}{|c|c|}
\hline Variabel & Indikator \\
\hline \multirow{4}{*}{ Keantusiasan } & Anak bisa fokus ketika bermain \\
\hline & $\begin{array}{l}\text { Anak menunjukkan kegembiraan } \\
\text { saat bermain }\end{array}$ \\
\hline & $\begin{array}{l}\text { Anak terlihat semangat saat } \\
\text { bermain }\end{array}$ \\
\hline & $\begin{array}{l}\text { Anak ikut bernyanyi dan berbicara } \\
\text { saat bermain }\end{array}$ \\
\hline \multirow{6}{*}{ Keaktifan } & Anak berbagi idenya \\
\hline & Anak mampu memimpin anak lain \\
\hline & Anak mau menolong anak lain \\
\hline & $\begin{array}{l}\text { Anak mampu mengajak temannya } \\
\text { untuk bergabung dalam permainan }\end{array}$ \\
\hline & Anak menunjukkan kreatifitas \\
\hline & $\begin{array}{l}\text { dalam membuat cerita dan } \\
\text { beraktivitas }\end{array}$ \\
\hline
\end{tabular}

Analisis Data

Analisis data dalam penelitian ini menggunakan statistik deskriptif kuantitatif yang bersifat eksploratif. Perhitungan dalam analisis data menghasilkan persentase pencapaian yang selanjutnya diinterprestasikan dengan menggunakan kalimat. Cara menghitung persentase respon anak berdasar lembar observasi menurut Yoni (2012) adalah sebagai berikut:

$$
\begin{aligned}
P= & \frac{\text { Skor keseluruhan yang diperoleh siswa }}{\text { Jumlah siswa } \mathrm{x} \text { skor maksimum }} \times 100 \% \\
& \text { Dari persentase tersebut, penelitian ini }
\end{aligned}
$$
mengambil 4 kriteria persentase, yang diadaptasikan dari pendapat Yoni (2012, pp. 175-176) dan prosedur penilaian di TK, yaitu: 
Jurnal Pendidikan dan Pemberdayaan Masyarakat, 3 (1), Maret 2016 - 92

Syarifatul Fitria, Suparno

Tabel 3. Kategori Kriteria Persentase Penilaian

\begin{tabular}{c|c}
\hline Kriteria & Persentase \\
\hline BSB & $75 \%-100 \%$ \\
(Berkembang Sangat Baik) & \\
BSH & $50 \%-74,99 \%$ \\
(Berkembang Sesuai Harapan) & \\
MB & $25 \%-49,99 \%$ \\
(Mulai Berkembang) & $\mathrm{oB} \%-24.99 \%$ \\
BB & \\
\hline
\end{tabular}

HASIL PENELITIAN DAN PEMBAHASAN

\section{Hasil Penelitian}

Hasil evaluasi formatif keterampilan membaca permulaan di kelas A nusantara berdasarkan 4 indikator keterampilan membaca permulaan yaitu anak mampu menyebutkan nama-nama karakter huruf, anak mampu menyebutkan bunyi huruf, anak mampu mencocokkan huruf besar dan huruf kecil, anak mampu menyebutkan tulisan sederhana dengan simbol yang melambangkannya yaitu sebanyak 93,33\% dari jumlah keseluruhan anak dalam kelas atau sejumlah 14 anak bisa dikategorikan berkembang sangat baik karena memilliki persentase pencapaian antara 75\%-10o\%, sedangkan $6,67 \%$ dari jumlah keseluruhan anak dalam kelas atau sejumlah 1 anak dapat dikategorikan memiliki kemampuan berkembang sesuai harapan karena memiliki persentase pencapaian antara 50\%-74,99\%.

Hasil evaluasi sumatif keterampilan membaca permulaan di kelas A nusantara berdasarkan 4 indikator keterampilan membaca permulaan yaitu sebanyak 93,33\% dari jumlah keseluruhan anak dalam kelas atau sejumlah 14 anak bisa dikategorikan berkembang sangat baik karena memilliki persentase pencapaian antara $75 \%-100 \%$, sedangkan 6,67\% dari jumlah keseluruhan anak dalam kelas atau sejumlah 1 anak dapat dikategorikan memiliki kemampuan berkembang sesuai harapan karena memiliki persentase pencapaian antara 50\%-74,99\%.

Implementasi metode pembelajaran berdasarkan karakter huruf dan suara/bunyi ini juga bertujuan mengetahui sejauhmana proses pembelajaran membaca permulaan mampu meningkatkan motivasi anak untuk belajar dengan melihat keantusiasan dan keaktifan anak selama proses pembelajaran berlangsung. Berikut diagram perbandingan hasil observasi keantusiasan dan keaktifan anak selama dilaksanakan proses pembelajaran.

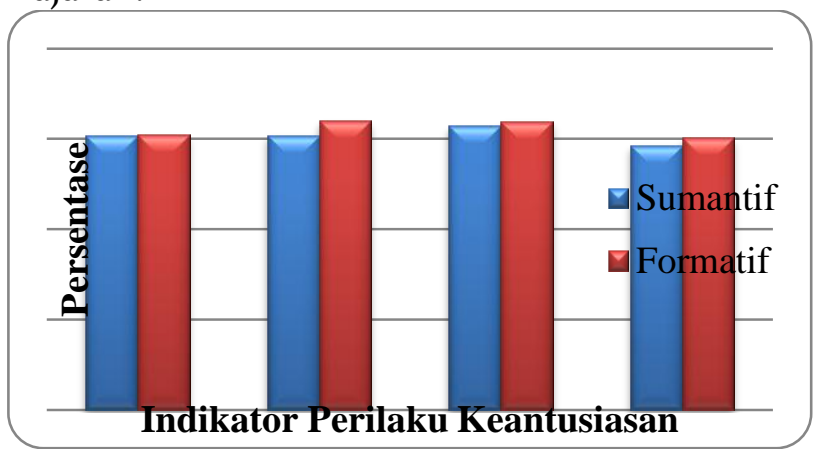

Gambar 1. Perbandingan Hasil Observasi Perilaku Keantusiasan

Keterangan :

1 : Anak bisa fokus ketika bermain

2 : Anak menunjukkan kegembiraan saat bermain

3: Anak terlihat semangat saat bermain

4 : Anak ikut bernyanyi dan berbicara saat bermain

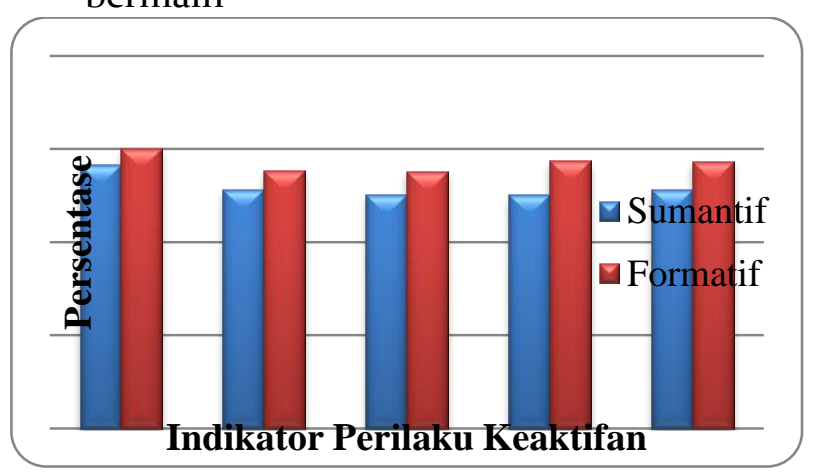

Gambar 2. Perbandingan hasil observasi perilaku keaktifan

Keterangan:

1 : Anak berbagi idenya

2: Anak mampu memimpin anak lain

3: Anak mau menolong anak lain

4: Anak mampu mengajak temannya untuk bergabung dalam permainan

5: Anak menunjukkan kreatifitas dalam membuat cerita dan beraktivitas

\section{Pembahasan}

Hasil evaluasi formatif dan evaluasi sumatif keterampilan membaca permulaan anak kelas A nusantara rata-rata anak memperoleh persentase sangat tinggi dan tinggi 


\section{Jurnal Pendidikan dan Pemberdayaan Masyarakat, 3 (1), Maret 2016 - 93}

Syarifatul Fitria, Suparno

sehingga dapat dikatakan kemampuan keterampilan membaca permulaan anak-anak di kelas tersebut sudah berkembang sangat baik dan berkembang sesuai harapan. Artinya dari hasil evaluasi formatif dan sumatif anak-anak kelas A program nusantara mampu menguasai keterampilan membaca permulaan sesuai standar pencapaian anak.

Hal terebut sesuai dengan penelitian Campbell, Torr \& Cologon (2012) motivasi penggunaan program fonik seperti letterland bahwa program mengurangi beban kerja guru, memberikan bukti nyata kepada orang tua tentang kesiapan sekolah anak mereka dan sebagai alat pemasaran untuk menarik orang tua. Menurut Phajane (2014, p. 477) mengajar fonik (dan keterampilan yang berkaitan dengan fonik, seperti kesadaran fonemik) merupakan cara yang lebih efektif untuk mengajarkan keterampilan membaca permulaan dengan menggunakan fonik daripada dengan tidak ada instruksi fonik pada anak.

Menurut pendapat Bradley \& Bryant (melalui Barratt-Pugh \& Rohl, 2001, p.72) dalam program pengajaran yang terdiri dari unsur nama huruf dan bunyi/suara huruf memiliki dampak dalam proses perkembangan membaca dan mengeja dibandingkan hanya mengajarkan kesadaran fonologi atau huruf alfabet secara terpisah. Dengan kata lain metode penggabungan antara pengenalan nama huruf dan pengenalan bunyi huruf-huruf tersebut akan menjadi optimal hasilnya jika dilakukan bersamasama, hal ini terbukti dari hasil penelitian di atas yang menunjukkan kemampuan anak yang tinggi dalam pencapaian keterampilan membaca permulaan.

Menurut Penelitian yang dilakukan Pramudyani \& Sugito (2014, p 171) tentang perkembangan bahasa yang dilakukan di KBTK Islam Al Azhar 31 Yogyakarta yaitu terbagi akan 3 cakupan yaitu pengungkapan bahasa, penerimaan bahasa, dan munculnya keaksaraan. Secara garis besar kemampuan anak di bidang bahasa kegiatan pembelajaran lebih banyak dilakukan pada aspek munculnya keaksaraan. Kegiatan mengenal huruf diberikan porsi yang lebih besar dibandingkan dengan perkembangan bahasa yang lainnya. Kegiatan pembelajaran dalam mengembangkan perkembangan bahasa anak, dapat dilakukan dengan berbagai metode agar anak menemukan sendiri pengalamannya. Metode yang sesuai dengan usia perkembangan anak usia dini antara lain, bermain drama dan story telling. Perkembangan bahasa anak akan lebih berkembang bila guru mampu memberikan stimulus yang membuat anak menikmati kegiatan pembelajaran seperti, kegiatan story telling. Perkembangan bahasa akan berjalan lurus dengan perkembangan kognitif anak, oleh karena itu dalam mengembangkan aspek perkembangan bahasa pada anak sebaiknya tidak hanya terfokus pada kemampuan anak dalam mengenal huruf dengan kegiatan membaca atau menulis. Berikan kegiatan pembelajaran yang membuat anak aktif menemukan pengalamannya sendiri.

Perbandingan hasil observasi keantusiasan anak selama mengikuti proses pembelajaran tersebut dapat diketahui bahwa dari keempat indikator skala keantusiasan tiga indikator memperoleh persentase sangat tinggi baik ketika evaluasi formatif maupun evaluasi sumatif. Ketiga indikator tersebut yaitu anak bisa fokus ketika bermain, anak menunjukkan kegembiraan saat bermain, dan anak terlihat bersemangat saat bermain. Sedangkan untuk indikator keempat yaitu anak ikut bernyanyi dan berbicara saat bermain antara data perbandingan hasil evaluasi formatif dan evaluasi Sumatif terdapat sedikit penurunan persentase di hasil evaluasi sumatif, hal ini bisa disebabkan karena aktivitas bernyanyi dan berbicara saat dilakukan pengambilan data Sumatif tidak sebanyak ketika pengambilan data formatif karena adanya keterbatasan waktu dalam melakukan kegiatan menyanyi dan berbicara/berdiskusi saat itu sehingga indikator ini tidak cukup banyak teramati oleh observer dibandingkan ketika pengambilan data formatif. Walaupun demikian persentase dari indikator keempat ini masih menunjukkan persentase yang tinggi hal ini menunjukkan bahwa anak-anak masih cukup antusias dalam bernyanyi dan berbicara saat bermain/ belajar membaca. Dengan keempat indikator yang menunjukkan persentase yang sangat tinggi dan tinggi tersebut membuktikan bahwa proses pembelajaran membaca per- 


\section{Jurnal Pendidikan dan Pemberdayaan Masyarakat, 3 (1), Maret 2016 - 94}

Syarifatul Fitria, Suparno

mulaan yang digunakan di kelas tersebut mampu membuat anak lebih antusias dalam belajar. Ketika anak antusias belajar maka dapat diartikan anak memiliki motivasi terhadap proses pembelajaran membaca permulaan dikelas mereka. Hal ini senada dengan dari Suyadi (2010, p.116) motivasilah yang nantinya akan menumbuhkan sikap optimistis, antusiasme, percaya diri dan tidak mudah menyerah. Motivasi adalah sesuatu yang mendorong seseorang untuk melakukan perbuatan atau tindakan guna mencapai harapan tertentu. Oleh sebab itu menjadi perhatian penting untuk membuat program yang dapat menumbuhkan motivasi anak untuk belajar.

Berdasarkan gambar 2 perbandingan hasil observasi keaktifan anak selama mengikuti proses pembelajaran tersebut diketahui bahwa hasil observasi perilaku keaktifan anak saat evaluasi formatif dan evaluasi sumatif menunjukkan adanya penurunan persentase di data observasi sumatif. Kondisi tersebut di atas terjadi karena saat dilakukan evaluasi Sumatif kelima indikator tersebut tidak dapat difasilitasi oleh guru dengan baik, karena alasan keterbatasan waktu guru hanya memberikan kegiatan bermain berupa lembar kerja pada anak, bersamaan dengan itu guru melakukan assesment individual pada anaknya. Hal ini juga karena materi assessment Sumatif merupakan keseluruhan huruf, sedangkan assesment formatif masing-masing hanya dua huruf tiap kali pelaksanaannya. Walaupun demikian hasil observasi keaktifan anak dalam hubungannya dengan teman kelas maupun guru kelasnya selama proses pembelajaran membaca permulaan ini tetap menunjukkan hasil yang baik terbukti kelima indikator ini masih memiliki persentase yang tinggi. Hal ini membuktikan bahwa proses pembelajaran membaca permulaan yang diterapkan di kelas tersebut dapat membuat anak lebih aktif berpartisipasi dalam proses pembelajaran baik itu bersama teman kelas maupun guru kelas. Hal ini senada dengan yang dinyatakan oleh Trianto (2011, p.11), yang terpenting dalam mengembangkan proses pembelajaran bagi pendidikan anak usia dini harus memperhatikan karakteristik anak dan kompetensi yang akan dicapai, interaksi dalam proses pembelajaran, alat/media dan penilaian.

\section{SIMPULAN DAN SARAN}

\section{Simpulan}

Hasil evaluasi formatif maupun sumantif keterampilan membaca permulaan anak kelas A nusantara berdasarkan empat indikator keterampilan membaca permulaan yaitu anak mampu menyebutkan namanama karakter huruf, anak mampu menyebutkan bunyi huruf, anak mampu mencocokkan huruf besar dan huruf kecil, anak mampu menyebutkan tulisan sederhana dengan simbol yang melambangkannya yaitu sebanyak 93,33\% dari jumlah keseluruhan anak dalam kelas atau sejumlah 14 anak bisa dikategorikan berkembang sangat baik, sedangkan $6,67 \%$ dari jumlah keseluruhan anak dalam kelas atau sejumlah satu anak dapat dikategorikan memiliki kemampuan berkembang sesuai harapan.

Hasil observasi keantusiasan anak kelas A nusantara bisa dikategorikan pada berkembang sangat baik dalam tiga indikator keantusiaan karena memiliki persentase antara 75\%-100, Ketiga indikator tersebut yaitu anak bisa fokus ketika bermain, anak menunjukkan kegembiraan saat bermain, dan anak terlihat bersemangat saat bermain. Dalam indikator keempat ini rata-rata anak masih bisa dikategorikan berkembang sesuai harapan karena memiliki persentase antara 50\%-74,99\%, hal ini menunjukkan bahwa anak-anak masih cukup antusias dalam bernyanyi dan berbicara saat bermain/belajar membaca. Dengan demikian dapat disimpulkan bahwa proses pembelajaran membaca permulaan di kelas tersebut mampu membuat anak lebih antusias dalam belajar.

Hasil observasi keaktifan anak dalam hubungannya dengan teman kelas maupun guru kelasnya selama proses pembelajaran membaca permulaan ini menunjukkan hasil sesuai yang diharapkan terbukti dari kelima indikator keaktifan anak masih memiliki persentase yang tinggi yaitu antara 50\%$74,99 \%$. Hal ini membuktikan bahwa metode pembelajaran membaca permulaan yang diterapkan dikelas tersebut dapat membuat anak lebih aktif berpartisipasi dalam proses 


\section{Jurnal Pendidikan dan Pemberdayaan Masyarakat, 3 (1), Maret 2016 - 95}

Syarifatul Fitria, Suparno

pembelajaran baik itu bersama teman kelas maupun guru kelas.

\section{Saran}

Bagi Guru yaitu guru sebaiknya bisa mengembangkan metode pembelajaran membaca permulaan dengan karakter huruf dan karakter suara untuk meningkatkan keterampilan membaca permulaan bagi anak. Khususnya guru perlu mengkaji ulang huruf-huruf yang memiliki nama karakter asing bagi anak, sehingga anak lebih mudah mengingat nama huruf dan suaranya melalui nama karakter huruf tersebut. Guru juga diharapkan selalu memberikan motivasi dan menciptakan suasana belajar melalui permainan yang menyenangkan agar anak lebih semangat dan percaya diri dalam mengikuti pembelajaran membaca permulaan.

Bagi Kepala sekolah hendaknya mendukung upaya guru untuk menerapkan dan mengembangkan permainan dalam pembelajaran membaca permulaan bagi anak di kelas.

\section{DAFTAR PUSTAKA}

Adedokun, M. O. (2013). Literacy in early childhood: implication for sustainable development. $1^{\text {st }}$ annual international interdiciplinary conference (AIIC). pp.466-472

Arikunto, S. (2009). Manajemen penelitian. Jakarta: PT Rineka Cipta

Barone, D.M., \& Mallete, M.H. (2013). Best practices literacy instruction. New York: The Guilford Press

Barratt-Pugh, C \& Rohl, M. (200o). Literacy learning in early years. Maidenhead, United Kingdom:Open University Press

Bodrova, E., Leong, D.J., \& Paynter, D. E. (1999). Literacy standard for preschool learners. Educational Leadership. Volume 57, No. 2 Oktober 1999. Diambil pada tanggal 27 November 2014 dari http://www.ascd.org/publications/edu cationalleadership/oct99/vol57/numo2 /Literacy-Standards-for-PreschoolLearners.aspx
Brown, C. S. (2014). Language and literacy development in the early years: Foundational skills that support emergent readers. Language and Literacy Spectrum, pp.24,35-49. Diambil pada tanggal 12 Juli 2015 dari http://search.proquest.com/docview/1 651859157 ? accountid $=12528$.

Callison, D., (1998). Authentic assessment. Bloomington: School Library Media Activities

Campbell, S., Torr, J., \& Cologon, K. (2012). Ant, Apples and the ABSs: The Use of Commercial Phonics Programmes in Prior-to-School Children's Services. Journal of Early Childhood Literacy, 12 (4), pp.367-388. Diambil pada tanggal 12 Juli 2015 dari http//ecl.sagepub.com//10.1177/146879 8411417377

Chen, A., \& Ennis, C.D. (2004). Goals, interests, and learning in physical education. The Journal of Educational Research, 97 (6), 329-339.doi: 10.3200/JOER.97.6.329-339

Combs, B. (2012). Assesing and addressing literacy needs: Case and instructional strategies. Thousands Oak: SAGE Publications, Inc.

Denton, K. \& West, J. (20 Maret 2002). Children's reading and mathematics achivement in kindergarten and first grade. Education statistics quarterly. Diambil pada tanggal 27 November 2014, dari http://nces.ed.gov/pubs2002/quaterly/ spring /Q3-1.asp.

Field, J. (2005). Psycholinguistics: A resource book for students. New York: Routledge.

Freese, G. (2003). Letterland teacher's guide. London : Harper Collins Publisher

Gordon, K.A., et.al. (2014). Early childhood education becoming professional. Thousands Oak: SAGE Publications, Inc.

Goouch, K \& Lambirth, A (2013). Teaching early reading and phonics: Creative approaches to early literacy. London: SAGE Publications, Inc. 
Johnson, J.E., Christie, J.F., \& Yawkey, T.D. (1999). Play and early childhood davelopment (2 $\left.{ }^{\text {nd }} E d\right)$. New York: Addison Wesley Longmann. Inc.

Kumara, A, et al. (2014). Kesulitan berbahasa pada anak. Yogyakarta: PT. Kanisius

Levey, S. \& Polirstok, S. (Eds.) (2011). Language development; understand-ing language diversity in classroom. California: SAGE

Madya, S. (2013). Metodologi pengajaran bahasa dari era prametode sampai era pascametode. Yogyakarta : UNY Press

Musfiroh, T. (2010). Uji produk model bacatulis akuisisi literasi. Jurnal Kependidikan, 39(1). Retrieved from http://journal.uny.ac.id/index.php/jk/ article/view/228

Papalia, D. E \& Feldman, R. D. (2014). Experience Human Development $\left(12^{\text {th }}\right.$ ed.). (terjemahan Fitriana Wuri Herarti) New York: Mc Graw Hill (Buku asli diterbitkan tahun 2011) Partini. (2010). Pengantar pendidikan anak usia dini. Yogyakarta : Grafindo Litera Media

Phajane, M. (2014). Introducing beginning reading using phonics approach. Mediterranean Journal of Social Sciences, 5(10), 477. Retrieved from http://www.mcser.org/journal/in dex.php/mjss/article/view/2916

Pramudyani, A., \& Sugito, S. (2014). Implementasi pembelajaran terpadu terhadap perkembangan anak usia dini di KB-TK Islam Al Azhar 31 Yogyakarta. Jurnal Pendidikan Dan Pemberdayaan Masyarakat, 1(2), pp.160-173. Retrieved from http://journal.uny.ac.id/index.php/jpp $\mathrm{m} /$ article/view/2686

Presiden Republik Indonsesia. (2010). Peraturan Pemerintah RI Nomor 17, Tahun 2010, tentang pengelolaan dan penyelenggaraan pendidikan

Rasyid, H., Mansyur., \& Suratno. (2012). Asesmen perkembangan anak usia dini. Yogyakarta : Gama Media

Reilly, V \& Ward, S.M. (2002). Very young learners. Oxford: Oxford University Press

Republik Indonesia. (2003). Undang-Undang RI Nomor 20, Tahun 2003, Tentang Sistem Pendidikan Nasional.

Smith, R. J. \& Johnson, D. D., (1980). Teaching children to read. New York: Addison Wesley Publishing Company

Snow, C. E., \& Van Hemel, S. B., (2008). Early childhood assessment: why, what and how. Washington, D.C.: The National Academies Press

Suyadi. (2010). Psikologi belajar PAUD. Yogyakarta: Pedagogia

Steinberg, D.D., Nagata, H., \& Aline, D.P. (2001). Psycholinguistics: Language, mind and world. London: Longman.

Trianto. (2011). Desain pengembangan pembelajaran tematik bagi anak usia dini TK/RA dan anak usia kelas awal SD/MI. Jakarta: Kencana prenada media grup.

Yoni, A. (2012). Menyusun penelitian tindakan kelas. Yogyakarta: Grup Relasi Inti Media 